\title{
Metabolizable energy and amino acid digestibility of soybean cake subjected to different dry extrusion temperatures for broilers
}

\author{
Marcos Fabio de Lima ${ }^{1}$, Cristina Amorim Ribeiro de Lima ${ }^{2}$, Felipe Dilelis ${ }^{2 *}$, Augusto Vidal da \\ Costa Gomes ${ }^{2}$, Leonardo Willian de Freitas ${ }^{2}$
}

\author{
${ }^{1}$ Instituto Federal de Educação, Ciência e Tecnologia do Rio de Janeiro, Campus Pinheiral, Pinheiral, RJ, Brasil. \\ ${ }^{2}$ Universidade Federal Rural do Rio de Janeiro, Departamento de Nutrição Animal e Pastagem, Seropédica, RJ, Brasil.
}

\begin{abstract}
Two experiments were conducted to evaluate the apparent metabolizable energy (AME), nitrogen-corrected apparent metabolizable energy (AMEn), and standardized ileal amino acid digestibility coefficient (SIDC) of extruded soybean cake (ESC) at four different extrusion temperatures: 90, 100, 110, and $120{ }^{\circ} \mathrm{C}$. In experiment 1,300 male broilers were randomly distributed into four treatments $\left(600 \mathrm{~g} \mathrm{~kg}^{-1}\right.$ reference diet $+400 \mathrm{~g} \mathrm{~kg}^{-1}$ of SBC at different extrusion temperatures $)+$ reference diet, with six replicates of 10 birds. A metabolic assay using the total excreta collection method was performed from 14 to 23 days to determine AME and AMEn. Quadractic effect of the extrusion temperature was observed, with the maximum AMEn value estimated as $3424.99 \mathrm{kcal} \mathrm{kg}^{-1}$ for $105.58{ }^{\circ} \mathrm{C}$. In experiment 2, 300 male broilers were randomly distributed into four treatments (453 $\mathrm{g} \mathrm{kg}^{-1}$ protein free diet $+547 \mathrm{~g} \mathrm{~kg}^{-1} \mathrm{SBC}$ at different extrusion temperatures) + protein free diet, with six replicates of 10 birds. Experimental diets were offered from 16 to 21 days, and at 21 days, birds were sacrificed by cervical dislocation for collection of the ileal digesta to determine the SIDC of ESC. The best SIDC values for lysine $(0.824 \%)$, methionine $(0.908 \%)$, and cysteine $(0.741 \%)$ were estimated at $117.72,114.40$, and $107.37{ }^{\circ} \mathrm{C}$, respectively. The other amino acids evaluated showed a linear response, with better SIDC values with increasing extrusion temperatures. The extrusion temperatures affect metabolizable energy and amino acid digestibility of soybean cake for broilers, being important the standardization of extrusion temperature to maximize the nutritional value of soybean cake used in broiler diets.
\end{abstract}

Key Words: byproduct, feed evaluation, metabolizability, nutritional value, poultry, total feces collection

\section{Introduction}

Anti-nutritional factors, such as trypsin inhibitors (TI), can limit the use of soybean, because dietary TI bind to pancreatic digestive enzymes, leading to reduced nitrogen and amino acid (AA) digestibility (Palliyeguru et al., 2011). The Kunitz TI, which are the major TI found in soybeans, are thermo-sensitive and can be inactivated by heat treatment (Woyengo et al., 2016). Extrusion is a multistep, multi-functional, and combined thermal-mechanical process that can gelatinize starch and inactivate a-amylase inhibitors, trypsin, chymotrypsin, and hemagglutinin activity (Nikmaram et al., 2017). The process also significantly reduces the microbial population, minimizes the loss of vitamins, and improves nutrient digestibility (Mantovani et al., 2011).

Received: March 13, 2018

Accepted: July 4, 2018

*Corresponding author: fdilelis@hotmail.com

Copyright (C) 2018 Sociedade Brasileira de Zootecnia. This is an Open Access article distributed under the terms of the Creative Commons Attribution License (http://creativecommons.org/licenses/by/4.0/), which permits unrestricted use, distribution, and reproduction in any medium, provided the original work is properly cited.
The different types of soybean processing confer different nutritional characteristics for birds, especially with respect to amino acid digestibility, since lysine, threonine, and methionine are especially sensitive to dry heating (Café et al., 2000) and mainly in the metabolizable energy contents of the extruded soybeans (Freitas et al., 2005). Large variations in nutritional values have been described for extruded soybeans (Costa et al., 2013), mainly due to the lack of standardization in the thermal processing used by the manufacturers (Nunes et al., 2015).

Although extruded full-fat soybeans can be used in the formulation of poultry diets, this product has a high fat content of approximately $190 \mathrm{~g} \mathrm{~kg}^{-1}$ (Rostagno et al., 2017). This high fat content limits the inclusion of full-fat soybeans in diets that need higher protein and lower energy levels. The pressing process is used to decrease this lipid concentration, because it reduces the fat content by producing a final extruded soybean cake (ESC) product and, consequently, increasing the levels of protein and other nutrients. Thus, ESC can be used in broiler feed to obtain adequate energy levels without including large amounts of additional vegetable oil. However, few studies have investigated the use of ESC processed at different temperatures for use in broiler feed. 
The objectives of this study were to evaluate the apparent metabolizable energy and determine the standardized ileal amino acid digestibility of soybean cake extruded at different temperatures.

\section{Material and Methods}

All experimental procedures were conducted according to the local Animal Use Committee, which approved the study under case number 23083.007756/ 2014-16.

To obtain the ESC, a batch of 30 tons of soybean grain of the cultivar BRS8560RR (Embrapa Soja, Londrina, PR, Brazil) from the state of Goiás, Brazil, was randomly separated. The raw soybean grain underwent cleaning, followed by separation of the peel and extrusion at four temperatures $\left(90,100,110\right.$, and $\left.120^{\circ} \mathrm{C}\right)$ by dry extrusion (Extruder model EXG 212, Greenpeças, Brazil) for a short period of time $(20 \mathrm{~s})$. The highest extrusion temperature was detected in the last ring of the extruder barrel, and the exposure time of soybeans to this temperature was $4 \mathrm{~s}$. After extrusion, the soybean was mechanically pressed (expeller model PLDS 3500, LDS, Brazil). We determined analysis of urease activity, protein solubility in potassium hydroxide, crude protein, ether extract, crude fiber, and moisture of the ESC at different temperatures (Table 1).

The test ingredients (ESC) and diets were analyzed for dry matter (Method 930.15), total ash (Method 942.05), nitrogen (Kjeldahl method, Method 976.06), crude fiber (Method 978.10), ether extract (Soxhlet fat analysis after $3 \mathrm{~N} \mathrm{HCl}$ acid hydrolysis, Method 920.39), and chromium (Method 985.01) as described by the Association of Official Analytical Chemists International (AOAC, 1995). Gross energy was determined using a bomb calorimeter (model 1341, Parr Instrument Company, Moline, IL, USA) with benzoic acid as the calibration standard. Solubility of $\mathrm{KOH}$ was determined as described by Parsons et al. (1991). Urease activity (UA) was determined according to the method of the American Oil Chemists Society (1980). The amino acid content of the diets and digesta were analyzed with high-performance liquid chromatography (HPLC) after hydrolysis with $6 \mathrm{~N} \mathrm{HCl}$ for $24 \mathrm{~h}$ at $110{ }^{\circ} \mathrm{C}$ by a commercial laboratory according to the method of Hagen et al. (1989).

A metabolic assay was conducted for the determination of apparent metabolizable energy (AME) and nitrogencorrected apparent metabolizable energy (AMEn) of the soybean cake extruded at different temperatures. The total excreta collection method was performed according to the methodology described by Sibbald (1963). The treatments consisted of $600 \mathrm{~g} \mathrm{~kg}^{-1}$ reference diet (Table 2) $+400 \mathrm{~g} \mathrm{~kg}^{-1}$ ESC subjected to extrusion temperatures of $90,100,110$, and $120^{\circ} \mathrm{C}$.

For calculation of the energy values of ingredients, a group of chickens, distributed similarly as described for the treatments, was given only the reference diet (Table 2); this group was not used in the statistical analysis.

A total of 300 slow-feathering Cobb $\times$ Cobb 500 male broilers were used. From the first to thirteenth days of age, the birds received an initial diet formulated to meet the recommendations of the Brazilian tables according to Rostagno et al. (2011). Birds were transferred to metabolic cages at 14 days of age. The five experimental diets were provided from 14 to 23 days old. Birds were adapted to the experimental conditions during the first five days (14 to 18 days) and the total excreta collection period was the last five days (19 to 23 days).

Two excreta collections were performed daily. The excreta from each cage were weighed immediately after each collection and stored in properly labelled plastic bags in a freezer $\left(-20^{\circ} \mathrm{C}\right)$ for subsequent analysis. The total feed

Table 1 - Basic chemical composition, urease activity, $\mathrm{KOH}$ solubility, total amino acids, and energy values of extruded soybean cake (ESC) samples at different temperatures

\begin{tabular}{lccccc}
\hline Analysis & $\begin{array}{c}\mathrm{ESC} \\
90^{\circ} \mathrm{C}\end{array}$ & $\begin{array}{c}\mathrm{ESC} \\
100{ }^{\circ} \mathrm{C}\end{array}$ & $\begin{array}{c}\mathrm{ESC} \\
110^{\circ} \mathrm{C}\end{array}$ & $\begin{array}{c}\mathrm{ESC} \\
120{ }^{\circ} \mathrm{C}\end{array}$ & $\mathrm{R}^{2}$ \\
\hline Urease activity $(\Delta \mathrm{pH})$ & 1.06 & 0.12 & 0.10 & 0.03 & \\
KOH solubility $(\%)$ & 92.82 & 90.01 & 81.43 & 81.00 & \\
Dry matter $\left(\mathrm{g} \mathrm{kg}^{-1}\right)$ & 936.2 & 936.4 & 937.0 & 940.1 & \\
Crude protein $\left(\mathrm{g} \mathrm{kg}^{-1}\right)$ & 405.9 & 414.1 & 407.6 & 400.1 & \\
Ether extract $\left(\mathrm{g} \mathrm{kg}^{-1}\right)$ & 120.02 & 119.99 & 120.04 & 119.96 & \\
Crude fiber $\left(\mathrm{g} \mathrm{kg}^{-1}\right)$ & 50.04 & 49.89 & 49.90 & 50.02 &
\end{tabular}

Total amino acids, expressed as $\mathrm{g} \mathrm{kg}^{-1}$ as-fed basis

$\begin{array}{lcccc}\text { Aspartic acid } & 47.6 & 48.4 & 45.8 & 46.2 \\ \text { Glutamic acid } & 74.6 & 76.1 & 74.5 & 72.9 \\ \text { Alanine } & 18.2 & 18.7 & 18.6 & 18.1 \\ \text { Arginine } & 29.3 & 30.4 & 30.3 & 29.3 \\ \text { Cysteine } & 7.4 & 7.2 & 7.0 & 6.3 \\ \text { Phenylalanine } & 21.1 & 21.7 & 21.6 & 21.0 \\ \text { Glycine } & 17.8 & 18.2 & 18.3 & 17.6 \\ \text { Isoleucine } & 19.7 & 20.4 & 20.2 & 19.5 \\ \text { Leucine } & 30.9 & 31.9 & 31.8 & 30.4 \\ \text { Lysine } & 25.9 & 26.4 & 25.8 & 24.7 \\ \text { Methionine } & 3.3 & 3.3 & 3.3 & 3.0 \\ \text { Methionine + cysteine } & 10.7 & 10.5 & 10.3 & 9.3 \\ \text { Proline } & 21.0 & 21.5 & 21.6 & 21.0 \\ \text { Serine } & 20.5 & 20.9 & 20.9 & 20.1 \\ \text { Tyrosine } & 15.0 & 15.3 & 14.8 & 14.4 \\ \text { Threonine } & 16.3 & 16.6 & 16.2 & 15.8 \\ \text { Valine } & 22.0 & 22.7 & 22.6 & 21.6\end{array}$

Energy values

$\begin{array}{llllll}\text { AME }\left(\mathrm{kcal} \mathrm{kg}^{-1}\right) & 3,392.7 & 3,561.8 & 3,803.7 & 3,381.7 & 0.768 \mathrm{Q}\end{array}$ \begin{tabular}{llllll} 
AMEn $\left(\mathrm{kcal} \mathrm{kg}^{-1}\right)$ & $3,072.7$ & $3,261.8$ & $3,503.8$ & $3,052.7$ & 0.787 \\
\hline
\end{tabular}

AME - apparent metabolizable energy; AMEn - nitrogen-corrected apparent metabolizable energy; $R^{2}$ - coefficient of determination; $Q$ - quadratic effect $(\mathrm{P}<0.05)$. 
consumed per experimental unit was computed at the end of the collection period. After the end of the experiment, the samples were thawed, weighed, and homogenized, and sub-samples of $400 \mathrm{~g}$ per replicate were removed, placed in an aluminum container, and pre-dried in a forced-air oven at $55^{\circ} \mathrm{C}$ for $72 \mathrm{~h}$. After pre-drying, the excreta were exposed to air until they reached room temperature and then weighed and milled in a knife mill with a $1-\mathrm{mm}$ sieve.

The crude energy (CE), dry matter (DM), and nitrogen values of the excreta, test diets, and reference diet were determined. Calculations of AME and AMEn for each ESC were performed based on the following equation according Borsatti et al. (2018):

$$
\mathrm{AME}=\mathrm{GEi}-[\mathrm{EOt}-(1-\mathrm{X}) \mathrm{EOr}] / \mathrm{X},
$$

in which GEi represents the gross energy of the ESC, EOt represents the energy output of the excreta originated from each experimental diet, EOr represents the energy output of excreta from the reference diet, and $\mathrm{X}$ represents the percentage of inclusion of each ESC.

The calculated AME was corrected to zero $\mathrm{N}$ retention (AMEn) using a factor of $8.22 \mathrm{kcal} \mathrm{g}^{-1}$ (Hill and Anderson, 1958).

Three hundred male broilers were used to determine the standardized ileal amino acid digestibility coefficients

Table 2 - Chemical composition and calculated nutrients of the reference diet of experiment ${ }^{1}$

\begin{tabular}{lc}
\hline Item & Reference diet \\
\hline Ingredient $\left(\mathrm{g} \mathrm{kg}^{-1}\right)$ & 560.0 \\
Corn & 365.0 \\
Soybean meal & 36.2 \\
Soybean oil & 10.2 \\
Limestone & 4.2 \\
Sodium chloride & 15.5 \\
Dicalcium phosphate & 3.0 \\
DL-methionine & 2.3 \\
L-lysine HCl & 1.0 \\
L-threonine & 1.0 \\
Vitamin premix & 1.0 \\
Mineral premix & 0.5 \\
Choline chloride & 0.1 \\
Antioxidant & \\
Calculated composition & \\
AMEn $\left(\mathrm{kcal} \mathrm{kg}^{3}\right)$ & 3050.0 \\
Crude protein $\left(\mathrm{g} \mathrm{kg}^{-1}\right)$ & 212.0 \\
Calcium $\left(\mathrm{g} \mathrm{kg}^{-1}\right)$ & 8.40 \\
NPP $\left(\mathrm{g} \mathrm{kg}^{-1}\right)$ & 4.00 \\
Sodium $\left.\mathrm{g} \mathrm{kg}^{-1}\right)$ & 0.210 \\
\hline
\end{tabular}

AMEn - nitrogen-corrected apparent metabolizable energy; NPP - non-phytate phosphorus.

${ }^{1}$ Vitamin premix provided per kilogram of diet: vitamin A, 10,000 IU; vitamin D3, 2,000 IU; vitamin E, $30 \mathrm{IU}$; vitamin $\mathrm{K} 3,3 \mathrm{mg}$; vitamin $\mathrm{B} 1,2 \mathrm{mg}$; vitamin $\mathrm{B} 2$, $2.5 \mathrm{mg}$; vitamin B6, $4 \mathrm{mg}$; vitamin B12, $5 \mathrm{mg}$; pantothenic acid, $12 \mathrm{mg}$; niacin, $12.5 \mathrm{mg}$; folic acid, $1 \mathrm{mg}$; and biotin, $0,1 \mathrm{mg}$.

${ }^{2}$ Mineral premix provided per kilogram of diet: manganese, $16 \mathrm{mg}$; zinc, $100 \mathrm{mg}$; iron, $100 \mathrm{mg}$; copper, $20 \mathrm{mg}$; iodine, $2 \mathrm{mg}$; selenium, $0.25 \mathrm{mg}$; nicarbazin, $125 \mathrm{mg}$; and enramycin, $10 \mathrm{mg}$.

${ }^{3}$ Beta-butylated hydroxytoluene (BHT) antioxidant.
(SIDC) in the ESC from the different temperature conditions. Birds were randomly distributed into four treatments + protein-free diet, in six replicates with 10 birds each, and fed the test diets from 16 to 21 days of age. Test diets (Table 3 ) were formulated to meet the recommendations of Rostagno et al. (2011), except for protein and amino acids. For the determination of endogenous loss and further calculations of standardized values, a protein-free diet (PFD) was also formulated and supplied to chickens, as described by Adedokun et al. (2008). Additionally, 0.5\% chromic oxide was incorporated into the experimental rations as an indicator for the calculation of the indigestibility factor of the studied diets.

After feeding for five days, at 21 days old, birds were slaughtered by cervical dislocation, and the ileal content $(5 \mathrm{~cm}$ of the ileocecal junction up to $40 \mathrm{~cm}$ toward the jejunum) was squeezed directly into a sampling cup. Digesta samples were frozen at $-20{ }^{\circ} \mathrm{C}$ for subsequent analysis. Test diets and ileal digesta samples were analyzed for amino acid composition according to the methodology described previously.

Ileal digestibility coefficients were obtained based on the results of the amino acid and chromic oxide indicator

Table 3 - Chemical composition of the experimental diet containing ESC at extrusion temperatures of $90,100,110$, and $120^{\circ} \mathrm{C}$ and of the protein-free diet

\begin{tabular}{lcc}
\hline Item & Diet with ESC & Protein-free diet \\
\hline Ingredient $\left(\mathrm{g} \mathrm{kg}^{-1}\right)$ & & \\
Extruded soybean cake & 547.0 & - \\
Starch & 282.9 & 782.0 \\
Soybean oil & 50.0 & 50.0 \\
Rice husk & 50.0 & 50.0 \\
Limestone & 15.0 & 10.0 \\
Sodium chloride & 4.5 & 4.4 \\
Dicalcium phosphate & 18.0 & 21.00 \\
Sugar & - & 50.0 \\
Washed sand & 25.0 & 25.0 \\
Chromium oxide & 5.0 & 5.0 \\
Vitamin premix & 1.0 \\
Mineral premix & 1.0 & 1.0 \\
Choline chloride & 1.0 & 0.50 \\
Antioxidant & 0.5 & 0.10 \\
Calculated composition & 0.1 & \\
AMEn $\left(\mathrm{kcal} \mathrm{kg}^{3}\right)$ & & $3,385.000$ \\
Crude protein $\left(\mathrm{g} \mathrm{kg} \mathrm{kg}^{-1}\right)$ & $3,218.000$ & 0.000 \\
Calcium $\left(\mathrm{g} \mathrm{kg}^{-1}\right)$ & 236.90 & 8.20 \\
NPP $\left(\mathrm{g} \mathrm{kg}^{-1}\right)$ & 10.00 & 3.90 \\
Sodium $\left(\mathrm{g} \mathrm{kg}^{-1}\right)$ & 4.80 & 1.80 \\
\hline
\end{tabular}

ESC - extruded soybean cake; AMEn - nitrogen-corrected apparent metabolizable energy; NPP - non-phytate phosphorus.

${ }^{1}$ Diet containing ESC at $90,100,110$, and $120^{\circ} \mathrm{C}$.

${ }^{2}$ Vitamin premix provided per kilogram of diet: vitamin A, 10,000 IU; vitamin D3, 2,000 IU; vitamin E, $30 \mathrm{IU}$; vitamin $\mathrm{K} 3,3 \mathrm{mg}$; vitamin B1, $2 \mathrm{mg}$; vitamin B2, $2.5 \mathrm{mg}$; vitamin B6, $4 \mathrm{mg}$; vitamin B12, $5 \mathrm{mg}$; pantothenic acid, $12 \mathrm{mg}$; niacin, $12.5 \mathrm{mg}$; folic acid, $1 \mathrm{mg}$; and biotin, $0,1 \mathrm{mg}$.

${ }^{3}$ Mineral premix provided per kilogram of diet: manganese, $16 \mathrm{mg}$; zinc, $100 \mathrm{mg}$; iron, $100 \mathrm{mg}$; copper, $20 \mathrm{mg}$; iodine, $2 \mathrm{mg}$; selenium, $0.25 \mathrm{mg}$; nicarbazin, $125 \mathrm{mg}$; and enramycin, $10 \mathrm{mg}$.

${ }^{4}$ Beta-butylated hydroxytoluene (BHT) antioxidant. 
analyses. Ileal endogenous amino acid and apparent ileal amino acid coefficient (AIDC) were determined and SIDC calculated according to equations adaptaded by Adedokun et al. (2008):

$$
\begin{gathered}
\mathrm{AAe}=[\text { AAid } \times(\text { Cdiet } / \mathrm{Cid})], \\
\mathrm{AIDC}=[1-(\mathrm{Cdiet} / \mathrm{Cid}) \times(\mathrm{AAid} / \mathrm{AAdiet}), \text { and } \\
\mathrm{SIDC}=\mathrm{AIDC}+(\mathrm{AAe} / \mathrm{AAesc}) \times 100),
\end{gathered}
$$

in which AAe represents ileal amino acid flow $(\mathrm{mg} / \mathrm{kg}$ of DMI), AAid represents the amino acid in ileal digesta $(\mathrm{mg} / \mathrm{kg})$, Cdiet represents diet chromium $(\mathrm{mg} / \mathrm{kg})$, Cid represents ileal chromium $(\mathrm{mg} / \mathrm{kg})$, AAdiet represents the amino acid in the $\operatorname{diet}(\mathrm{mg} / \mathrm{kg})$, and AAesc represents amino acid content of the ESC ( $\mathrm{g} / \mathrm{kg}$ of DM).

The experimental design was completely randomized, with four treatments and six replicates of 10 broilers. The analysis of variance was performed according to the statistical model below:

$$
\mathrm{Yij}=\mu+\mathrm{Gi}+\varepsilon \mathrm{ij}
$$

in which Yij is the observation of the effect of extrusion temperatures $i$, at replication $j ; \mu$ is the overall mean; $G i$ is the effect of extrusion temperatures; and $\varepsilon i j$ is the random error associated with each observation.

The statistical analysis was performed using the statistical program Sisvar (version 5.6). The data from the AME, AMEn, and SIDC were subjected to ANOVA $(\alpha=0.05)$, in which the main quantitative effect (soybean extrusion temperature) was studied by regression analysis. The optimum extrusion temperature was estimated using the quadratic model with $\alpha=0.05$.

\section{Results}

The results of the present study showed that AME and AMEn of soybean cake were influenced by extrusuion temperatures (Table 1). A quadratic effect $(\mathrm{P}<0.05)$ was observed for the soybean cake extrusion temperature $\left(\mathrm{Y}=1.6079 \mathrm{x}^{2}+339.51 \mathrm{x}-14497 ; \mathrm{r}^{2}=0.787 \%\right)$, with the highest AMEn value of $3,424.99 \mathrm{kcal} \mathrm{kg}^{-1}$ obtained at a temperature of $105.58{ }^{\circ} \mathrm{C}$.

The total amino acid values were analyzed in each soybean cake at different extrusion temperatures (Table 1). The Trp concentration and its digestibility were not measured due to the low content and special hydrolysis conditions needed.

According to the regression analysis, all SIDC studied (Table 4) were significantly $(\mathrm{P}<0.05)$ influenced by the soybean cake extrusion temperature. Quadratic effects $(\mathrm{P}<0.05)$ were observed for the SIDC values of lysine $\left(\mathrm{Y}=-0.0266 \mathrm{x}^{2}+6.265 \mathrm{x}-286.21, \mathrm{R}^{2}=0.861 \%\right)$, methionine $\left(\mathrm{Y}=-0.0242 \mathrm{x}^{2}+5.5368 \mathrm{x}-225.95, \mathrm{R}^{2}=0.957 \%\right)$ and cysteine $\left(\mathrm{Y}=-0.1111 \mathrm{x}^{2}+24.373 \mathrm{x}-1234.4, \mathrm{R}^{2}=0.839 \%\right)$; the best estimated extrusion temperatures were 117.72, 114.40 , and $107.37{ }^{\circ} \mathrm{C}$ for SIDC values of $0.824,0.908$, and 0.741 , respectively.

The extrusion temperature of the soybean cake positively and linearly $(\mathrm{P}<0.05)$ increased the standardized ileal digestibility coefficients of the amino acids valine, threonine, tyrosine, serine, proline, leucine, isoleucine,

\begin{tabular}{|c|c|c|c|c|c|c|c|}
\hline \multirow{2}{*}{ Variable } & \multicolumn{4}{|c|}{ Standardized ileal digestibility coefficient } & \multirow{2}{*}{ CV $(\%)$} & \multirow{2}{*}{\multicolumn{2}{|c|}{$\mathrm{R}^{2}$}} \\
\hline & $\operatorname{ESC} 90^{\circ} \mathrm{C}$ & $\mathrm{ESC} 100^{\circ} \mathrm{C}$ & $\mathrm{ESC} 110^{\circ} \mathrm{C}$ & $\mathrm{ESC} 120^{\circ} \mathrm{C}$ & & & \\
\hline \multicolumn{8}{|c|}{ Essential amino acids ${ }^{1}$} \\
\hline Methionine & $0.767(2.5)$ & $0.839(2.80)$ & $0.915(3.00)$ & $0.891(2.70)$ & 6.39 & 0.957 & Q \\
\hline Lysine & $0.635(16.3)$ & $0.699(18.4)$ & $0.853(22.0)$ & $0.810(20.0)$ & 9.40 & 0.861 & Q \\
\hline Threonine & $0.632(10.3)$ & $0.698(11.6)$ & $0.784(12.7)$ & $0.789(12.5)$ & 11.92 & 0.915 & $\mathrm{~L}$ \\
\hline Arginine & $0.816(23.9)$ & $0.880(26.8)$ & $0.918(27.8)$ & $0.933(27.3)$ & 3.03 & 0.925 & $\mathrm{~L}$ \\
\hline Leucine & $0.689(21.3)$ & $0.748(23.9)$ & $0.825(26.2)$ & $0.862(26.2)$ & 5.51 & 0.985 & $\mathrm{~L}$ \\
\hline Isoleucine & $0.667(13.1)$ & $0.749(15.3)$ & $0.756(15.3)$ & $0.865(16.9)$ & 7.29 & 0.913 & $\mathrm{~L}$ \\
\hline Valine & $0.660(14.5)$ & $0.729(16.5)$ & $0.733(16.6)$ & $0.851(18.4)$ & 8.16 & 0.882 & $\mathrm{~L}$ \\
\hline Phenylalanine & $0.706(14.6)$ & $0.787(17.1)$ & $0.849(18.4)$ & $0.885(18.6)$ & 4.71 & 0.973 & $\mathrm{~L}$ \\
\hline \multicolumn{8}{|c|}{ Nonessential amino acids ${ }^{1}$} \\
\hline Alanine & $0.694(12.6)$ & $0.735(13.7)$ & $0.821(15.3)$ & $0.842(15.2)$ & 7.06 & 0.952 & $\mathrm{~L}$ \\
\hline Aspartic acid & $0.817(39.2)$ & $0.824(39.6)$ & $0.908(41.6)$ & $0.926(42.3)$ & 4.78 & 0.834 & $\mathrm{~L}$ \\
\hline Cysteine & $0.423(3.1)$ & $0.603(4.30)$ & $0.807(5.60)$ & $0.533(3.40)$ & 8.50 & 0.839 & Q \\
\hline Glutamic acid & $0.823(61.4)$ & $0.835(63.5)$ & $0.908(67.7)$ & $0.914(66.6)$ & 3.73 & 0.874 & $\mathrm{~L}$ \\
\hline Glycine & $0.646(11.5)$ & $0.698(12.7)$ & $0.796(14.6)$ & $0.829(14.6)$ & 7.25 & 0.966 & $\mathrm{~L}$ \\
\hline Proline & $0.794(16.7)$ & $0.823(17.7)$ & 0.913 (19.7) & $0.940(19.7)$ & 2.74 & 0.947 & $\mathrm{~L}$ \\
\hline Serine & $0.697(14.3)$ & $0.741(15.5)$ & $0.836(17.5)$ & $0.814(16.4)$ & 9.29 & 0.802 & $\mathrm{~L}$ \\
\hline Tyrosine & $0.713(10.7)$ & $0.829(12.7)$ & $0.870(12.9)$ & $0.909(13.1)$ & 4.10 & 0.918 & $\mathrm{~L}$ \\
\hline
\end{tabular}
glycine, phenylalanine, arginine, alanine, glutamic acid,

Table 4 - Standardized ileal digestibility coefficients and standardized ileal digestible amino acid concentrations of extruded soybean cake (ESC) subjected to different extrusion temperatures ${ }^{1}$

$\mathrm{CV}$ - coefficient of variation; $\mathrm{R}^{2}$ - coefficient of determination; $\mathrm{L}$ - linear effect, $\mathrm{P}<0.05 ; \mathrm{Q}$ - quadratic effect, $\mathrm{P}<0.05$.

${ }^{1}$ Expressed in percentages based on natural matter; the figures in the parentheses are the standardized ileal digestible amino acid contents (expressed as $\%$ on natural matter). 
and aspartic acid. The SIDC values for these amino acids ranged from 0.632 to 0.817 , for soybean cake extruded at $90{ }^{\circ} \mathrm{C}$, and from 0.789 to $0.940 \%$, for soybean cake extruded at $120^{\circ} \mathrm{C}$.

\section{Discussion}

The metabolizable energy value from the ESC obtained in this experiment $\left(3,424 \mathrm{kcal} \mathrm{kg}^{-1}\right)$ differed from the value described in Brazilian Tables For Poultry and Swine $\left(2,811 \mathrm{kcal} \mathrm{kg}^{-1}\right)$ (Rostagno et al., 2017). This difference may be attributed to the ether extract value of $100.5 \mathrm{~g} \mathrm{~kg}^{-1}$ found by Rostagno et al. (2017), which differed from the value of $120 \mathrm{~g} \mathrm{~kg}^{-1}$ obtained in the present study. Scotta et al. (2016) found an AMEn value of 2,467 kcal kg-1 in an extruded soybean cake with an $87.5 \mathrm{~g} \mathrm{~kg}^{-1} \mathrm{EE}$ content, highlighting that the soybean extrusion process is not standardized, which results in variations in the chemical compositions and energetic values. Values of AMEn in the range of 2,682 to 3,564 kcal kg${ }^{-1}$ were reported by Loeffler et al. (2013) in cold-pressed soybean meal with EE contents varying from 76.7 to $138.0 \mathrm{~g} \mathrm{~kg}^{-1}$.

The AME and AMEn of soybean cake presented a quadratic response by extrusion temperatures, with the highest AMEn value of $3,424.99 \mathrm{kcal} \mathrm{kg}^{-1}$ obtained at a temperature of $105.58^{\circ} \mathrm{C}$. The passage of starch in the grains through the extrusion process at moderate temperatures leads to its hydrolyzation from the effects of heat, pressure, and moisture, which facilitate enzymatic digestion. An increase in protein digestibility is observed in extruded food, mainly because the modification of its tertiary structure causes a reduction in the hydrolysis time in bird intestines (Cheftel, 1986). The increase in extrusion temperature is also responsible for inactivation of trypsin inhibitors, resulting in a better digestibility by poultry. Therefore, increased starch and protein digestibility, and reduced trypsin inhibitors, as showed by the urease activity results, may have been responsible for the increase in the AMEn of ESC. However, high extrusion temperatures can lead to the occurrence of the Maillard reaction, in which sugars bind to amino acids forming complexes that are biologically unavailable to the animal (Cheftel, 1986). Similarly, high temperatures may cause loss of sulfhydryl groups (Miller, 2002) and reduction in AMEn values.

Among the amino acid content of ESC, the total lysine, threonine, and leucine values found agree with values reported by Rostagno (2017), whereas total valine, isoleucine, phenylalanine, glycine, and serine values were higher, and the total methionine and cysteine values were lower than those described in the Brazilian Tables for
Poultry and Swine. Glycine, isoleucine, and lysine values were similar to those described by Scottá et al. (2013), while serine, proline, glutamic acid, phenylalanine, leucine, arginine, and methionine values were lower, and cysteine, aspartic acid, alanine, valine, and threonine values were higher.

Standardized ileal digestibility coefficients of all amino acids studied were significantly $(\mathrm{P}<0.05)$ influenced by the soybean cake extrusion temperature. Quadratic effects were observed for SIDC values of lysine, methionine, and cysteine, and linear effect $(\mathrm{P}<0.05)$ for the other amino acids. The SIDC values for these amino acids ranged from 0.632 to 0.817 , for soybean cake extruded at $90{ }^{\circ} \mathrm{C}$, and from 0.789 to 0.940 , for soybean cake extruded at $120^{\circ} \mathrm{C}$. These results for ESC at $120^{\circ} \mathrm{C}$ agreed in a consistent way with the ones reported by Ganzer et al. (2017), with SIDC of ESC ranging from 0.79 to 0.92 . As for the significant effect for methionine and cysteine, the high temperatures may cause loss of sulfhydryl groups and the formation of disulfide cross links, with reduction of cysteine and methionine digestibility (Miller, 2002).

The increase in the extrusion temperature may inactivate TI, resulting in a better amino acid SIDC. Some of these effects can be explained by the possible reduction of TI with the increase in the extrusion temperature, as shown by the decreasing UA (1.06 to 0.03). These results are in accordance with Loeffler et al. (2013), who evaluated cold-pressed soybean cake (UA 1.51 to 1.96) and soybean meal (UA 0.02) and found better SIDC values for the lowest UA soybean product. A better amino acid digestibility coefficient was also reported by Jahanian and Rasouli (2016) when soybean meal was subjected to extrusion, with a reduction in the UA $(0.23$ to 0.0$)$ and TI $\left(16,800\right.$ to 2,400 units $\left.\mathrm{g}^{-1}\right)$.

However, too high extrusion temperatures most likely trigger the Maillard reaction, in which reducing sugars bind to the lysine epsilon group and make amino acid biologically unavailable to the animal (Cheftel, 1986), resulting in a reduction of lysine digestibility. According to Lan et al. (2010) after $110{ }^{\circ} \mathrm{C}$, the peptides crosslinked with sugar increase. In this study, a reduction of the lisyne SIDC was observed at $120^{\circ} \mathrm{C}$ when compared with $110^{\circ} \mathrm{C}$, in which the best extrusion temperature estimated to higher lysine SIDC by the regression analysis was $117,72^{\circ} \mathrm{C}$.

The extrusion temperatures affected the metabolizable energy and AA digestibility of soybean cake for broilers. Many studies have evaluated the feeding value of soybean products for poultry in controlled conditions wherein processing temperatures were well defined (Leeson and Atteh, 1996; Ruiz et al., 2004; Clarke and Wiseman, 2007; 
Powell et al., 2011). Ruiz et al. (2004) evaluated the amino acid digestibility of raw full fat soybean and five extrusion temperatures, from 113 to $150{ }^{\circ} \mathrm{C}$ and concluded that both performance and in vivo amino acid digestibility data failed to demonstrate that full fat soybean was over-processed in any of the temperatures used. Clarke and Wiseman (2007) extruded full fat soybeans at four temperatures $\left(90,110,130\right.$, and $\left.160{ }^{\circ} \mathrm{C}\right)$ and observed growing linear effects on apparent amino acid digestibility coefficients of lysine, methionine, and cysteine. In this study, it was possible verify that the processing temperatures on soybean cake affect the digestibility of lysine, methionine, and cysteine, and the metabolizable energy. The rate of destruction of TI for given temperatures may vary between extruder models and other parameters (Clarke and Wiseman, 2007), being difficult to determine whether one factor or a combination of factors is responsible for the differences seen among different studies. The results highlight the importance of the standardization of extrusion process to maximize the nutritional value of soybean cake used in broiler diets.

\section{Conclusions}

The nitrogen-corrected apparent metabolizable energy and standardized amino acid digestibility coefficient values are significantly influenced by the extrusion temperatures of soybean cake. The highest nitrogen-corrected apparent metabolizable energy value $\left(3424.99 \mathrm{kcal} \mathrm{kg}^{-1}\right)$ is obtained with a soybean cake extrusion temperature of approximately 105.6 ${ }^{\circ} \mathrm{C}$. The best soybean cake extrusion temperatures estimated for the standardized amino acid digestibility values are $117.72{ }^{\circ} \mathrm{C}$ for lysine, $114.40{ }^{\circ} \mathrm{C}$ for methionine, and $107.37{ }^{\circ} \mathrm{C}$ for cysteine. The standardization of extrusion temperatures is important to maximize the nutritional value of soybean cake used in broiler diets.

\section{Acknowledgments}

We are grateful to the company Reginaves Indústria e Comércio de Aves Ltda., for supporting this research.

\section{References}

Adedokun, S. A.; Adeola, O.; Parsons, C. M.; Lilburn, M. S. and Applegate, T. J. 2008. Standardized ileal amino acid digestibility of plant feedstuffs in broiler chickens and turkey poults using a nitrogen-free or casein diet. Poultry Science 87:2535-2548. https://doi.org/10.3382/ps.2007-00387

American Oil Chemists Society. 1980. Urease activity. Official Method Ba 9-58. American Oil Chemists Society, Champaign, IL.
AOAC - Association of Official Analytical Chemists. 1995. Official methods of analysis of AOAC International. 16th ed. Washington, DC, USA.

Borsatti, L.; Vieira, S. L.; Stefanello, C.; Kindlein, L.; OviedoRondón, E. O. and Angel, C. R. 2018. Apparent metabolizable energy of by-products from the soybean oil industry for broilers: acidulated soapstock, glycerin, lecithin, and their mixture. Poultry Science 97:124-130. https://doi.org/10.3382/ps/pex269

Café, M. B.; Sakomura, N. K.; Junqueira, O. M.; Carvalho, M. R. B. and Del Bianchi, M. 2000. Determination of the nutritional values of processe full-fat soybeans for poultry. Brazilian Journal of Poultry Science 2:67-74. https://doi.org/10.1590/S1516$635 X 2000000100010$

Cheftel, J. C. 1986. Nutritional effects of extrusion-cooking. Food Chemistry 20:263-283.

Clarke, E. and Wiseman, J. 2007. Effects of extrusion conditions on trypsin inhibitor activity of full fat soybeans and subsequent effects on their nutritional value for young broilers. British Poultry Science 48:703-712. https://doi.org/10.1080/00071660701684255

Costa, E. M. S.; Figueiredo, A. V.; Lopes, J. B.; Ribeiro, F. B.; Silva, S. R. G.; Almendra, S. N. O.; Carvalho Filho, D. U. and Lima, D. C. P. 2013. Desempenho de frangos de corte alimentados com dietas contendo grão integral e coprodutos da soja em ambiente com calor cíclico. Revista Brasileira de Saúde e Produção Animal 14:710-720. https://doi.org/10.1590/S1519-99402013000400010

Freitas, E. R.; Sakomura, N. K.; Neme, R.; Santos, A. L. and Fernandes, J. B. 2005. Efeito do processamento da soja integral sobre a energia metabolizável e a digestibilidade dos aminoácidos para aves. Revista Brasileira de Zootecnia 34:1938-1949. https:// doi.org/10.1590/S1516-35982005000600018

Ganzer, C.; Siegert, W.; Kluth, H.; Bennewitz, J. and Rodehutscord, M. 2017. Prececal amino acid digestibility of soybean cake in fast- and slow-growing broiler chickens. Poultry Science 96:2804-2810. https://doi.org/10.3382/ps/pex090

Hagen S. R.; Frost, B. and Augustin, J. 1989. Precolumn phenylisothiocyanate derivatization and liquid-chromatography of amino-acids in food. Journal of the Association of Official Analytical Chemists 72:912-916.

Hill, F. W. and Anderson, D. L. 1958. Comparison of metabolizable energy and productive energy determinations with growing chicks. Journal of Nutrition 64:587-603. https://doi.org/10.1093/ jn/64.4.587

Jahanian, R. and Rasouli, E. 2016. Effect of extrusion processing of soybean meal on ileal amino acid digestibility and growth performance of broiler chicks. Poultry Science 95:2871-2878. https://doi.org/10.3382/ps/pew178

Lan, X.; Liu, P.; Xia, S.; Jia, C.; Mukunzi, D.; Zhang, X.; Xia, W.; Tian, H. and Xiao, Z. 2010. Temperature effect on the nonvolatile compounds of Maillard reaction products derived from xylose-soybean peptide system: Further insights into thermal degradation and cross-linking. Food Chemistry 120:967-972. https://doi.org/10.1016/j.foodchem.2009.11.033

Leeson, S. J. and Atteh, J. O. 1996. Response of broiler chicks to dietary full-fat soybeans extruded at different temperatures prior to and after grinding. Animal Feed Science and Technology 57:239-245. https://doi.org/10.1016/0377-8401(95)00847-0

Loeffler, T.; Shim, M. Y.; Beckstead, R. B.; Batal, A. B. and Pesti, G. M. 2013. Amino acid digestibility and metabolizable energy of genetically selected soybean products. Poultry Science 92:1790-1798. https://doi.org/10.3382/ps.2012-02299

Mantovani, D.; Filho, L. C. and Corazza, M. L. 2011. Physical and chemical characteristics studies during the processing of soybean used in monogastric feeding. Semina: Ciências Agrárias 32:1163-1168. 
Miller, E. L. 2002. Protein nutrition requirements of farmed livestock and dietary supply. Food and Agriculture Organization. Available at: <http://www.fao.org/docrep/007/y5019e/y5019e06. $\mathrm{htm}>$. Accessed on: July 2, 2018.

Nikmaram, N.; Leong, S. Y.; Koubaa, M.; Zhu, Z.; Barba, F. J.; Greiner, F.; Oey, I. and Roohinejad, S. 2017. Effect of extrusion on the anti-nutritional factors of food products: An overview. Food Control 79:62-73. https://doi.org/10.1016/j.foodcont.2017.03.027

Nunes, R. V.; Broch, J.; Polese, C.; Eyng, C. and Pozza, C. 2015. Nutritional and energetic evaluation of deactivated full-fat soybean for poultry. Revista Caatinga 28:143-151.

Palliyeguru, M. W. C. D.; Rose, S. P. and Mackenzie, A. M. 2011. Effect of trypsin inhibitor activity in soya bean on growth performance, protein digestibility and incidence of sub-clinical necrotic enteritis in broiler chicken flocks. Brazilian Journal of Poultry Science 52:359-367. https://doi.org/10.1080/00071668.2011.577054

Parsons, C. M.; Hashimoto, K.; Wedekind, K. J. and Baker, D. H. 1991. Soybean protein solubility in potassium hydroxide: An in vitro test of in vivo protein quality. Journal of Animal Science 69:2918-2924.

Powell, S.; Naranjo, V. D.; Lauzon, D.; Bidner, T. D.; Southern, L. L. and Parsons, C. M. 2011. Evaluation of an expeller-extruded soybean meal for broilers. Journal of Applied Poultry Research 20:353-360. https://doi.org/10.3382/japr.2010-00305

Rostagno, H. S.; Albino, L. F. T.; Donzele, J. L.; Gomes, P. C.; Oliveira, R. F. M.; Lopes, D. C.; Ferreira, A. S. and Barreto, S. L. T. 2011. Brazilian tables for poultry and swine - Composition of feedstuffs and nutritional requirements. 3rd ed. Viçosa, MG, Brasil.
Rostagno, H. S.; Albino, L. F. T.; Hannas, M. I.; Donzele, J. L.; Sakomura, N. K.; Perazzo, F. G.; Saraiva, A.; Abreu, M. L. T.; Rodrigues, P. B.; Oliveira, R. F.; Barreto, S. L. T. and Brito, C. O. 2017. Brazilian tables for poultry and swine - Composition of feedstuffs and nutritional requirements. 4th ed. Viçosa, MG, Brasil.

Ruiz, N.; Belalcázar, F. and Díaz, G. J. 2004. Quality control parameters for commercial full-fat soybeans processed by two different methods and fed to broilers. Journal of Applied Poultry Research 13:443-450. https://doi.org/10.1093/japr/13.3.443

Scottá, B. A.; Albino, L. F. T.; Rostagno, H. S.; Gomide, A. P. C.; Campos, P. F.; Vieira, R. A. and Demuner, L. F. 2013. Coeficientes de digestibilidade e conteúdo de aminiácidos digestíveis em alimentos proteicos para frangos de corte. Revista Brasileira de Agropecuária Sustentável 3:151-157.

Scotta, B. A.; Albino, L. F. T.; Brustolini, P. C.; Gomide, A. P. C.; Campos, P. F. and Rodrigues, V. V. 2016. Determination of chemical composition and metabolizable energy values of some protein feeds for broiler chicken. Ciência Animal Brasileira 17:501-508. https://doi.org/10.1590/1089-6891v17i421347

Sibbald, I. R. and Slinger, S. J. A. 1963. A biological assay for metabolizable energy in poultry feed ingredients together with findings which demonstrate some of the problems associated with evalution of fats. Poultry Science 42:313-325. https://doi.org/ $10.3382 /$ ps.0420313

Woyengo, T. A.; Beltranena, E. and Zijlstra, R. T. 2016. Effect of antinutritional factors of oilseed co-products on feed intake of pigs and poultry. Animal Feed Science and Technology 233:76-86. https://doi.org/10.1016/j.anifeedsci.2016.05.006 